\title{
The Study of the Comparison of the Performance of State Training and Education Complexes with Separate Schools in Tehran Education and Training Organization
}

\author{
Tieh Ranjbar Ahmad Abadi \\ M.A in Educational Sciences (curriculum planning Major), Islamic Azad University, Central Tehran Branch, Tehran, Iran \\ Email: ranjbar52@gmail.com \\ Parinaz Banisi
}

Assistant Professor, Tehran West Branch , Islamic Azad University, Tehran, Iran

\section{Doi:10.5901/mjss.2016.v7n4s2p257}

\begin{abstract}
Public educational complexes are one of the new designs to improve the country's educational system copied from the experience of establishing the cluster schools in some developing and developed countries in the world. According to this design, schools use each other resources so that the benefits obtained could be shared. The main aim of this study was to compare the performances of different urban public educational complexes with separate schools in education of Tehran City. To accomplish this goal, survey research method and questionnaires were used to collect information in which the questionnaire was obtained from Kirr and Henny Theory. Content validity of the questionnaire was confirmed by experts in this field and its reliability was confirmed by Cronbach's alpha Test. The statistical population of the study included all 3,000 managers, assistants, teachers and educational staff in education of Tehran City among whom 341 individuals were selected through Bula sample size and random cluster sampling method. The results indicated that the mean performance of separate schools was better than urban public educational complexes in education of Tehran City.
\end{abstract}

Keywords: public educational complexes, educational, teaching, research, service, professional development, evaluation, and publication performances.

\section{Introduction}

In a world where change is the rule rather than the exception and education as a driving force of sustainable development is among the main factors of human life, logical and reasonable ideas cannot be expected from fundamental transformation without fitting conventional structures and arrangements.

It has been for long decades that schools as the main institutions, structures and educational systems are assigned the mission and to fulfill the goals of education. The schools with the current format, at the height of isolation to each other, are condemned to survive in which weaken activities and human and material resources the day to day (Haji Babaei, 2011). Various definitions of the educational complex were presented. Supreme Education Council (2002) defined the educational complex as a collection of public schools in the same place having special authorities run participatory. Ribgester and Edwards (1998) knew cluster schools as nearby schools that help and cooperate in implementation different satisfaction affairs and they are among the schools mutually use each other resources and share their benefits. But separate schools are the ones managed separately in different levels of schools with finance, space and facilities separate from each other and are not connected to each other.

In education, the role of human resources is very important and teachers are the most important agents in the development of qualitative education and their impact on society is so much that can be said the prosperity of the country is in hands of those who are engaged in the education of its children (Spector, 2000). Teacher is a leader who tries to create an environment in which students could find opportunity to learn new and correct information and complete their incomplete and inaccurate knowledge (Goleman, 1998). Schools are the place of expression of any planning and decision-making in education. Practical and realistic evaluation of educational policies in countries requires the value of their attention to management structure and the scope of operation and decision-making of schools authorities (Bakhtiyari and Naeini, 2012).

According to many experts in education, is some parts of Iran's educational issues are arising from the current 
centralized system which puts the school under its control and limit their developments. In recent years, Supreme Education Council to resolve this problem took actions to decentralize the educational system and with the approval some regulations, give some authorities of educational staff to the province, school districts and schools. However, the holding factors of the centralized system are still very robust and decentralization measures, always encounters social, cultural, economic and political barriers (Haghani and Baratali, 2012).

One of the main problems for policy makers and planners has always been how the effectiveness, efficiency and deployment of educational system can be developed to the maximum level so that it could provide the development of communities as well as the welfare and happiness of mankind more than it used to be the past. During the past five decades (from 1960 onwards) to respond the previous concerns and following challenges, board of trustees and participatory school, free school, cluster schools and educational systems in the theoretical and practical have been entered. In other words, educational complexes are among the strategies to strengthen the qualitative dimensions and to address issues and challenges facing the education system. This approach is a good opportunity to develop educational justice, more utilization of human and material resources (Haji Babaei, 1390). The plan of establishing educational complexes is one of the new plans in improving the country's education system and as a new management method to enable schools; it is modeled from the experience of establishing cluster schools in different countries of the world (Navidi, 2009). Here are a few examples of recent researches as follow:

Haji Babaei (2012) carried out a study entitled educational complexes did pure life and a fundamental transformation of education and concluded that the education system in Iran experienced the creation of educational complexes which unfortunately due to lack of scientific and executive supports in various levels of decision making failed. Salimi Nejad et al (2002) studied urban educational complexes from the perspective of opportunities, threats and strategies using educational methods (Swot) and concluded that although the heads of the complexes despite the best efforts hoped for the success of the project, but they were not satisfied of the project due to the elements' negligence associated to the complexes. But the current situation of the complexes is in a state that the appropriate strategies are to maintain them.

There are different reasons that this topic was selected to study including the researcher's personal interest and field of the study in the educational complex environment; the needs in the research community of the country to compare the performances of urban public educational complexes with separate schools in education of Tehran City because there has not been any studies conducted in this field in urban educational complexes as well as education schools in Tehran city. Therefore with regard to the issues mentioned and the importance of comparing the performances of urban public educational complexes with separate schools, it can be claimed that the researcher's concern in the study is to compare the performances of urban public educational complexes with separate schools in education of Tehran City; Therefore, The main research question is:

How are the performances statuses of urban public educational complexes and separate schools in education of Tehran City?

\section{Research Hypotheses}

$\mathrm{H} 1$ : There is a significant difference between the teaching performances of urban public educational complexes and separate schools in education of Tehran City.

$\mathrm{H} 2$ : There is a significant difference between the educational performances of urban public educational complexes and separate schools in education of Tehran City.

$\mathrm{H} 3$ : There is a significant difference between the research performances of urban public educational complexes and separate schools in education of Tehran City.

$\mathrm{H} 4$ : There is a significant difference between the professional development performances of urban public educational complexes and separate schools in education of Tehran City.

$\mathrm{H} 5$ : There is a significant difference between the service performances of urban public educational complexes and separate schools in education of Tehran City.

H6: There is a significant difference between the publication performances of urban public educational complexes and separate schools in education of Tehran City.

$\mathrm{H} 7$ : There is a significant difference between the evaluation performances of urban public educational complexes and separate schools in education of Tehran City.

H8: There is a significant difference between the performances of urban public educational complexes for girls and urban public educational complexes for boys. 


\section{Methodology}

The research is in the field of descriptive-correlative research and functional in terms of its objective. The statistical population of the study included all 3,000 managers, assistants, teachers and educational staff in education of Tehran City with associate degrees, bachelor's and master's degrees and higher in the fields of research among whom 341 individuals were selected through Bula sample size and random cluster sampling method. Distribution of sampling is shown in Table 1:

Table 1: Sampling design of the study sample $(n=341)$

\begin{tabular}{|l|c|c|c|c|c|c|c|c|c|c|}
\hline Sample group & District 1 & District 1 & District 3 & District 6 & District 10 & District 13 & District 5 & District 9 & District 17 & District 18 \\
\hline Male managers & 2 & 2 & 6 & 3 & 3 & 5 & 6 & 4 & 5 & 4 \\
\hline Male vices & 10 & 10 & 8 & 5 & 4 & 5 & 6 & 4 & 5 & 4 \\
\hline Male vices experts & 4 & 5 & 4 & 6 & 5 & 3 & 3 & 6 & 2 & 2 \\
\hline Male teachers & 2 & 2 & 6 & 3 & 3 & 5 & 6 & 4 & 4 & 5 \\
\hline Female managers & 3 & 3 & 6 & 2 & 2 & 6 & 5 & 5 & 4 & 4 \\
\hline Female vices & 4 & 6 & 5 & 4 & 5 & 3 & 6 & 2 & 3 & 2 \\
\hline Female vices experts & 6 & 2 & 5 & 6 & 3 & 4 & 3 & 2 & 4 & 5 \\
\hline Female teachers & 2 & 6 & 2 & 3 & 5 & 3 & 4 & 6 & 5 & 4 \\
\hline
\end{tabular}

The present study data was obtained using a questionnaire with 59 questions taken from the theory of Kiir and Haney (2001) which measures components' performance as follow:

Teaching performance: in the present study, teaching duties are measured in 15 questions.

Educational performance: in the present study, educational duties are measured in 11 questions.

Research performance: in the present study, research duties are measured in 8 questions.

Service performance: in the present study, service duties are measured in 5 questions.

Publication performance: in the present study, publication duties are measured in 4 questions. questions.

Professional development performance: in the present study, professional development duties are measured in 9

Evaluation performance: in the present study, evaluation duties are measured in 7 questions.

The validity of the questionnaire was the type of formal and its reliability was Cronbach's alpha which the value obtained for it equals to 0.82 . In order to describe the data, the frequency tables and graphs were used. Moreover, in order to better describe the data, central measures and dispersion parameters were used. The $t$ of two independent groups was also used to analyze the research hypotheses.

\section{Findings}

\subsection{Descriptive Statistics}

In this section using frequency tables, frequency percentage, and column graphs the frequency and dependent variables in this study were described.

\subsection{Describing field variables}

\subsubsection{Distribution of participants based on sex}

Table 2 shows the frequency and percent frequency distribution of participants based on sex.

Table 2: Distribution of participants based on sex

\begin{tabular}{|c|c|c|}
\hline Sex & Frequency & Frequency percentage \\
\hline Female & 123 & 35.8 \\
\hline Male & 221 & 64.2 \\
\hline Sum & 344 & 100 \\
\hline
\end{tabular}




\subsubsection{Distribution of participants based on degree}

Table 3 shows the frequency and percent frequency distribution of participants based on degree.

Table 3: Distribution of participants based on degree

\begin{tabular}{|l|c|c|}
\hline Degree & Frequency & Frequency percentage \\
\hline Diploma & 29 & 8.4 \\
\hline Associate & 55 & 16 \\
\hline B.A & 186 & 54.1 \\
\hline M.A & 66 & 19.2 \\
\hline Ph.D. or higer & 8 & 2.3 \\
\hline Sum & 344 & 100 \\
\hline
\end{tabular}

\subsubsection{Describing dependent variables}

\subsubsection{Teaching performance}

Table 4 shows the frequency and percent frequency distribution of participants based on teaching performance of public complexes and separate schools.

Table 4: Distribution of participants based on teaching performance

\begin{tabular}{|l|c|c|c|c|c|c|}
\hline \multirow{2}{*}{ Teaching performance } & \multicolumn{3}{|c|}{ Separate schools } & \multicolumn{3}{c|}{ Public complexes } \\
\cline { 2 - 7 } & Cumulative percent & percent & Frequency & Cumulative percent & percent & Frequency \\
\hline Poor & 3.5 & 3.5 & 6 & 20.9 & 20.9 & 36 \\
\hline Average & 18.6 & 15.1 & 26 & 77.9 & 57 & 98 \\
\hline Excellent & 100 & 81.4 & 140 & 100 & 22.1 & 38 \\
\hline
\end{tabular}

\subsubsection{Educational performance}

Table 5 shows the frequency and percent frequency distribution of participants based on educational performance of public complexes and separate schools.

Table 5: Distribution of participants based on educational performance

\begin{tabular}{|l|c|c|c|c|c|c|}
\hline Educational performance & \multicolumn{3}{|c|}{ Separate schools } & \multicolumn{3}{c|}{ Public complexes } \\
\cline { 2 - 8 } & Cumulative percent & percent & Frequency & Cumulative percent & percent & Frequency \\
\hline Poor & 6.4 & 6.4 & 11 & 18 & 18 & 31 \\
\hline Average & 19.8 & 13.4 & 23 & 50.6 & 32.6 & 56 \\
\hline Excellent & 100 & 80.2 & 138 & 100 & 49.4 & 85 \\
\hline
\end{tabular}

\subsubsection{Research performance}

Table 6 shows the frequency and percent frequency distribution of participants based on research performance of public complexes and separate schools.

Table 6: Distribution of participants based on research performance

\begin{tabular}{|l|c|c|c|c|c|c|}
\hline \multirow{2}{*}{ research performance } & \multicolumn{3}{|c|}{ Separate schools } & \multicolumn{3}{c|}{ Public complexes } \\
\cline { 2 - 7 } & Cumulative percent & percent & Frequency & Cumulative percent & percent & Frequency \\
\hline Poor & 9.3 & 9.3 & 16 & 40.7 & 40.7 & 70 \\
\hline Average & 26.2 & 16.9 & 29 & 86.6 & 45.9 & 79 \\
\hline Excellent & 100 & 73.8 & 127 & 100 & 13.4 & 23 \\
\hline
\end{tabular}




\subsubsection{Service performance}

Table 7 shows the frequency and percent frequency distribution of participants based on service performance of public complexes and separate schools.

Table 7: Distribution of participants based on service performance

\begin{tabular}{|l|c|c|c|c|c|c|}
\hline service performance & \multicolumn{3}{|c|}{ Separate schools } & \multicolumn{3}{c|}{ Public complexes } \\
\cline { 2 - 7 } & Cumulative percent & percent & Frequency & Cumulative percent & percent & Frequency \\
\hline Poor & 9.9 & 9.9 & 17 & 25.6 & 25.6 & 44 \\
\hline Average & 20.9 & 11 & 19 & 66.3 & 40.7 & 70 \\
\hline Excellent & 100 & 79.1 & 136 & 100 & 33.7 & 58 \\
\hline
\end{tabular}

\subsubsection{Publication performance}

Table 8 shows the frequency and percent frequency distribution of participants based on publication performance of public complexes and separate schools.

Table 8: Distribution of participants based on publication performance

\begin{tabular}{|l|c|c|c|c|c|c|}
\hline \multirow{2}{*}{ publication performance } & \multicolumn{3}{|c|}{ Separate schools } & \multicolumn{3}{c|}{ Public complexes } \\
\cline { 2 - 7 } & Cumulative percent & percent & Frequency & Cumulative percent & percent & Frequency \\
\hline Poor & 14.5 & 14.5 & 25 & 29.7 & 29.7 & 51 \\
\hline Average & 27.3 & 12.8 & 22 & 66.3 & 36.6 & 63 \\
\hline Excellent & 100 & 72.7 & 125 & 100 & 33.7 & 58 \\
\hline
\end{tabular}

\subsubsection{Professional development performance}

Table 9 shows the frequency and percent frequency distribution of participants based on professional development performance of public complexes and separate schools.

Table 9: Distribution of participants based on professional development performance

\begin{tabular}{|l|c|c|c|c|c|c|}
\hline \multirow{2}{*}{ professional development performance } & \multicolumn{3}{|c|}{ Separate schools } & \multicolumn{3}{c|}{ Public complexes } \\
\cline { 2 - 7 } & Cumulative percent & percent & Frequency & Cumulative percent & percent & Frequency \\
\hline Poor & 9.9 & 9.9 & 17 & 24.4 & 24.4 & 42 \\
\hline Average & 26.2 & 16.3 & 28 & 69.8 & 45.3 & 78 \\
\hline Excellent & 100 & 73.8 & 127 & 100 & 30.2 & 52 \\
\hline
\end{tabular}

\subsubsection{Evaluation performance}

Table 10 shows the frequency and percent frequency distribution of participants based on evaluation performance of public complexes and separate schools.

Table 10: Distribution of participants based on evaluation performance

\begin{tabular}{|l|c|c|c|c|c|c|}
\hline \multirow{2}{*}{ evaluation performance } & \multicolumn{3}{|c|}{ Separate schools } & \multicolumn{3}{c|}{ Public complexes } \\
\cline { 2 - 7 } & Cumulative percent & percent & Frequency & Cumulative percent & percent & Frequency \\
\hline Poor & 9.9 & 9.9 & 17 & 23.3 & 23.3 & 40 \\
\hline Average & 20.3 & 10.5 & 18 & 67.4 & 44.2 & 76 \\
\hline Excellent & 100 & 79.7 & 137 & 100 & 32.6 & 56 \\
\hline
\end{tabular}




\section{The Performance of Public and Separate Schools}

In order to measure the variable of sum performance, it was presented in teaching, educational, research, professional development, service, publication, and evaluation dimensions based on Kiir and Henny Theory (85.2001). Accordingly to create the variable of sum performance, different dimensions of the variable were first combined together then were ranked into three components of weak, average, and excellent. Table 11 shows the frequency and percent frequency distribution of participants based on sum performance of public complexes and separate schools.

Table 11: Distribution of participants based on sum performance

\begin{tabular}{|l|c|c|c|c|c|c|}
\hline \multirow{2}{*}{ sum performance } & \multicolumn{3}{|c|}{ Separate schools } & \multicolumn{3}{c|}{ Public complexes } \\
\cline { 2 - 7 } & Cumulative percent & percent & Frequency & Cumulative percent & percent & Frequency \\
\hline Poor & 7 & 7 & 12 & 21.5 & 21.5 & 37 \\
\hline Average & 22.7 & 15.7 & 27 & 48.8 & 48.8 & 84 \\
\hline Excellent & 100 & 77.3 & 133 & 29.7 & 29.7 & 51 \\
\hline
\end{tabular}

\section{Inferential Statistics}

\subsection{Main hypothesis}

HO: There are is not a significant difference between the performances of urban public educational complexes and separate schools in education of Tehran City.

$\mathrm{H} 1$ : There are is a significant difference between the performances of urban public educational complexes and separate schools in education of Tehran City.

Table 12: Comparing the mean of educational complex performance based on the type of school

\begin{tabular}{|c|c|c|c|c|c|}
\hline School & Number & mean & Standard deviation & T value & Significance level \\
\hline Complex & 172 & 2.76 & 97.84 & \multirow{2}{*}{-7.06} & \multirow{2}{*}{0.000} \\
\hline Separate & 172 & 3.44 & 79.67 & & \\
\hline
\end{tabular}

According to the above table, the $t$ value with the level of fallibility of 0.05 and degree of freedom of 170 is more than the table (the significance level is also less than the level of fallibility of 0.05 ); therefore null hypothesis is rejected and with $95 \%$ confidence it can be said there are differences between the performances of urban public educational complexes and separate schools in education of Tehran City and this difference is in the interest of separate schools.

\subsection{First secondary hypothesis}

HO: There are is not a significant difference between the teaching performances of urban public educational complexes and separate schools in education of Tehran City.

$\mathrm{H} 1$ : There are is a significant difference between the teaching performances of urban public educational complexes and separate schools in education of Tehran City.

Table 13: Comparing the mean of teaching performance of educational complex based on the type of school

\begin{tabular}{|c|c|c|c|c|c|}
\hline School & Number & mean & Standard deviation & T value & Significance level \\
\hline Complex & 172 & 71.46 & 25.86 & \multirow{2}{*}{-7.236} & \multirow{2}{*}{0.000} \\
\hline Separate & 172 & 89.19 & 18.16 & & \\
\hline
\end{tabular}

According to the above table, the $t$ value with the level of fallibility of 0.05 and degree of freedom of 170 is more than the table (the significance level is also less than the level of fallibility of 0.05 ); therefore null hypothesis is rejected and with 95\% confidence it can be said there are differences between the teaching performances of urban public educational complexes and separate schools in education of Tehran City and this difference is in the interest of separate schools. 


\subsection{Second secondary hypothesis}

$\mathrm{HO}$ : There are is not a significant difference between the educational performances of urban public educational complexes and separate schools in education of Tehran City.

$\mathrm{H} 1$ : There are is a significant difference between the teaching performances of urban public educational complexes and separate schools in education of Tehran City.

Table 14: Comparing the mean of educational performance of educational complex based on the type of school

\begin{tabular}{|c|c|c|c|c|c|}
\hline School & Number & mean & Standard deviation & T value & Significance level \\
\hline Complex & 172 & 51.78 & 18.66 & \multirow{2}{*}{-7.543} & 0.000 \\
\hline Separate & 172 & 65.21 & 14.02 & & \\
\hline
\end{tabular}

According to the above table, the t value with the level of fallibility of 0.05 and degree of freedom of 170 is more than the table (the significance level is also less than the level of fallibility of 0.05 ); therefore null hypothesis is rejected and with $95 \%$ confidence it can be said there are differences between the educational performances of urban public educational complexes and separate schools in education of Tehran City and this difference is in the interest of separate schools.

\subsection{Third secondary hypothesis}

$\mathrm{HO}$ : There are is not a significant difference between the research performances of urban public educational complexes and separate schools in education of Tehran City.

H1: There are is a significant difference between the research performances of urban public educational complexes and separate schools in education of Tehran City.

Table 15: Comparing the mean of research performance of educational complex based on the type of school

\begin{tabular}{|c|c|c|c|c|c|}
\hline School & Number & mean & Standard deviation & T value & Significance level \\
\hline Complex & 172 & 36.58 & 15.88 & -6.032 & 0.000 \\
\hline Separate & 172 & 45.81 & 12.27 & -03 & \\
\hline
\end{tabular}

According to the above table, the $t$ value with the level of fallibility of 0.05 and degree of freedom of 170 is more than the table (the significance level is also less than the level of fallibility of 0.05 ); therefore null hypothesis is rejected and with 95\% confidence it can be said there are differences between the research performances of urban public educational complexes and separate schools in education of Tehran City and this difference is in the interest of separate schools.

\subsection{Fourth secondary hypothesis}

HO: There are is not a significant difference between the professional development performances of urban public educational complexes and separate schools in education of Tehran City.

$\mathrm{H1}$ : There are is a significant difference between the professional development performances of urban public educational complexes and separate schools in education of Tehran City.

Table 16: Comparing the mean of professional development performance of educational complex based on the type of school

\begin{tabular}{|c|c|c|c|c|c|}
\hline School & Number & mean & Standard deviation & T value & Significance level \\
\hline Complex & 172 & 41.28 & 16.02 & \multirow{2}{*}{-6.276} & 0.000 \\
\hline Separate & 172 & 51.47 & 14.05 & & \\
\hline
\end{tabular}

According to the above table, the $t$ value with the level of fallibility of 0.05 and degree of freedom of 170 is more than the table (the significance level is also less than the level of fallibility of 0.05 ); therefore null hypothesis is rejected and with $95 \%$ confidence it can be said there are differences between the professional development performances of urban public educational complexes and separate schools in education of Tehran City and this difference is in the interest of separate schools. 


\subsection{Fifth secondary hypothesis}

HO: There are is not a significant difference between the service performances of urban public educational complexes and separate schools in education of Tehran City.

$\mathrm{H} 1$ : There are is a significant difference between the service performances of urban public educational complexes and separate schools in education of Tehran City.

Table 17: Comparing the mean of service performance of educational complex based on the type of school

\begin{tabular}{|c|c|c|c|c|c|}
\hline School & Number & Mean & Standard deviation & T value & Significance level \\
\hline Complex & 172 & 23.75 & 11.40 & \multirow{2}{*}{-5.11} & 0.000 \\
\hline Separate & 172 & 29.11 & 7.69 & & \\
\hline
\end{tabular}

According to the above table, the $t$ value with the level of fallibility of 0.05 and degree of freedom of 170 is more than the table (the significance level is also less than the level of fallibility of 0.05 ); therefore null hypothesis is rejected and with 95\% confidence it can be said there are differences between the service performances of urban public educational complexes and separate schools in education of Tehran City and this difference is in the interest of separate schools.

\subsection{Sixth secondary hypothesis}

HO: There are is not a significant difference between the publication performances of urban public educational complexes and separate schools in education of Tehran City.

$\mathrm{H} 1$ : There are is a significant difference between the publication performances of urban public educational complexes and separate schools in education of Tehran City.

Table 18: Comparing the mean of publication performance of educational complex based on the type of school

\begin{tabular}{|c|c|c|c|c|c|}
\hline School & Number & mean & Standard deviation & T value & Significance level \\
\hline Complex & 172 & 18.09 & 8.69 & -4.90 & \multirow{2}{*}{0.000} \\
\hline Separate & 172 & 22.75 & 8.90 & & \\
\hline
\end{tabular}

According to the above table, the $t$ value with the level of fallibility of 0.05 and degree of freedom of 170 is more than the table (the significance level is also less than the level of fallibility of 0.05 ); therefore null hypothesis is rejected and with $95 \%$ confidence it can be said there are differences between the publication performances of urban public educational complexes and separate schools in education of Tehran City and this difference is in the interest of separate schools.

\subsection{Seventh secondary hypothesis}

$\mathrm{HO}$ : There are is not a significant difference between the evaluation performances of urban public educational complexes and separate schools in education of Tehran City.

$\mathrm{H1}$ : There are is a significant difference between the evaluation performances of urban public educational complexes and separate schools in education of Tehran City.

Table 19: Comparing the mean of evaluation performance of educational complex based on the type of school

\begin{tabular}{|c|c|c|c|c|c|}
\hline School & Number & mean & Standard deviation & T value & Significance level \\
\hline Complex & 172 & 33.18 & 14.22 & \multirow{2}{*}{-5.63} & 0.000 \\
\hline Separate & 172 & 40.80 & 10.57 & & \\
\hline
\end{tabular}

According to the above table, the $t$ value with the level of fallibility of 0.05 and degree of freedom of 170 is more than the table (the significance level is also less than the level of fallibility of 0.05 ); therefore null hypothesis is rejected and with 95\% confidence it can be said there are differences between the evaluation performances of urban public educational complexes and separate schools in education of Tehran City and this difference is in the interest of separate schools. 


\subsection{Eighth secondary hypothesis}

HO: There are is not a significant difference between the performances of urban public educational complexes for girls and urban public educational complexes for boys.

$\mathrm{H} 1$ : There are is a significant difference between the performances of urban public educational complexes for girls and urban public educational complexes for boys.

Table 12: Comparing the mean of educational complex performance based on sex

\begin{tabular}{|c|c|c|c|c|c|}
\hline Sex & Number & mean & Standard deviation & T value & Significance level \\
\hline Male & 123 & 2.90 & 92.57 & \multirow{2}{*}{-2.88} & 0.004 \\
\hline Female & 221 & 3.21 & 95.33 & & \\
\hline
\end{tabular}

According to the above table, the $t$ value with the level of fallibility of 0.05 and degree of freedom of 170 is more than the table (the significance level is also less than the level of fallibility of 0.05 ); therefore null hypothesis is rejected and with 95\% confidence it can be said There are differences between the performances of urban public educational complexes for girls and urban public educational complexes for boys and this difference is in the interest of urban public educational complexes for girls.

\section{Discussion and Conclusion}

In the present study the performances of urban public educational complexes and separate schools in education of Tehran City were compared. To do so, various dimensions of performance variable including, teaching, educational, research, professional development, service, publication, and evaluation in terms of public urban complexes and separate schools were analyzed. The results indicated that all dimensions of performance variable of separate schools were better than in the public educational complexes. In fact, establishing cluster schools or educational complexes as one of the effective measures were done to correct and improve educational management in specific environment, to use common schools under the support of complex from each other fiscal, physical, and human facilities as well as developing the culture of group working and etc. the findings of the research rejected the research hypotheses in which it was expected that the performance of public educational complexes are better than in the separate schools. In other words, although the capacity of the project to upgrade the quality of education and money-saving to use resource in certain situations is undeniable, but there is doubt about the existence of such a situation in our country despite the findings of the present study. The reason for the failure of such a design at schools can be numerous including the need and motivation of clustering in other countries was more serious and real than our country. Also problems such as reduced registration rate, threatening the survival of small rural schools, isolation of teachers and etc. in our country are not very serious and real and given the providing the resources from the state treasury, there is not enough motivation for saving in costs. Participatory management of cluster schools is subject to special conditions that little attention or no attention to it may stop any activities related to the management of missions and fulfilling of its objectives. Based on the available evidence, motivation and supporting context necessary for adoption and support of this approach has not been provided as required, a content which could admit the innovation and motivate beneficiary's human factors to stimulate natural growth (Saki, 2004).

In summary, it can be said that the success of the project at the school is subject to special economic, social and cultural conditions and the evidence in this study indicates that the ideal condition was not provided to implement the educational complex. According to what was said and given the clear findings, it seems that implementing the educational complex at schools is not appropriate and its implementation with conditions sustainability will be nothing but misleading changes and innovation. So it can be said, the continuation of activities at separate schools against the design will show better performance.

\section{References}

Bakhtiyari, A. \& Naeini, M. (2012). Cultural approach to educational complexes. Proceedings of first conference of urban public educational complexes, Organization of Libraries, Museums and Documents Center of Astan Quds Razavi, Tehran.

Goleman, D. (1998). Working with emotional intelligence. New York: Banton.

Haghani, F. \& Baratali, M. (2012). Educational complexes, a new approach in reforming the country's education system. Proceedings of 
first conference of urban public educational complexes, Organization of Libraries, Museums and Documents Center of Astan Quds Razavi, Tehran.

Haji Babaei, H., (2012). Public educational complexes and pure life and a fundamental transformation of education. Proceedings of first conference of urban public educational complexes, Organization of Libraries, Museums and Documents Center of Astan Quds Razavi, Tehran.

Ministry of Education (2002). The act of Six hundred and seventy-second session of the Supreme Council of Education in the field of the establishment of educational complexes, Tehran, Supreme Education Council Secretariat.

Navidi, A. (2012). Evaluation of the rural educational complex in Iran. Rural Development . Journal of Social Science, 4 (2): 75-98.

Ribchester, C \& Edwards, W. J. (1998). Cooperation in the countryside: Small primary School. Cluster Education Studies, 24 (3), 98114.

Saki, R. (2003). The establishment of educational complexes experience in Iran, fears and hopes. Journal of Education, No. 77, pp. 712.

Spector, P. (2000). Indastrail an Organizational Psychology. Journal of Social and Clinical Psychology, 24, 1030 - 1050. 